\title{
Evaluation of antinociceptive and anti-inflammatory activities of the topical preparation of Cipura paludosa (Iridaceae)
}

\author{
José Antônio Paixão da SILVA NETOํㅗㄴ Larissa Dias MENEZES ${ }^{1}$, Gúbio Oliveira GOMES ${ }^{1}$, Elise Marques \\ Freire CUNHA ${ }^{2}$, Mariângela Soares de AZEVEDO ${ }^{2}$, Vania Moraes FERREIRA ${ }^{1}$, Mônica Valero da SILVA ${ }^{1 *}$ \\ Faculdade de Ciências da Saúde, Departamento de Ciências Farmacêuticas, Universidade de Brasília (UnB), Campus Universitário Darcy Ribeiro. CEP: $70910-900$, Phone: 0055 \\ 61 8111-6758, Fax: 0055613273 - 0105. Brasília, DF, Brazil. Jap.sn@hotmail.com, laladyas@gmail.com, gubiounb@yahoo.com.br, vmmf@unb.br, mvalero2@unb.br \\ 2 Departamento de Química, Universidade Federal de Rondônia (UNIR), CEP: 78980-500. Porto Velho, Rondônia, Brazil. elisemarquesquimica@hotmail.com, mari. \\ azeved02008@yahoo.com.br \\ * Corresponding Author: mvalero2@unb.br
}

\section{ABSTRACT}

Alho do mato (Cipura paludosa, Iridaceae) is a medicinal plant found in the Amazon rain forest, North of Brazil. It has been used to treat algic, inflammatory and infectious processes. The aim of this study was to evaluate the anti-inflammatory and antinociceptive action of the crude Cipura paludosa ethanolic extract at concentrations ranging between 2.0 and $4.0 \%$ in Oil and Water cream formulations for topical use. The physical-chemical stability of the formulations was monitored over a six-month period with the use of accelerated stability tests. In order to evaluate the anti-inflammatory and antinociceptive activities, we used a paw edema test induced by carrageenan and a formalin test, respectively. The paw edema test showed that there was a statistical difference in the control group in relation to the treatments. The formalin test did not confirm antinociceptive action of the treatments with the extract in the early phase of the test. However, statistical difference was confirmed for the treatments in relation to the control in the late phase. The antinociceptive and anti-inflammatory activities of Cipura paludosa preparations, as demonstrated in the results, at least partially support the ethno-medical uses of this plant. KEYWORDS: Oil and Water Cream, medicinal plant, paw edema test, formalin test.

\section{Avaliação das atividades antinociceptiva e anti-inflamatória de preparação tópica de Cipura paludosa (Iridaceae)}

\begin{abstract}
RESUMO
Allho do mato (Cipura paludosa, Iridaceae) é uma planta medicinal encontrada na floresta Amazônica, norte do Brasil. Essa planta tem sido usada para tratar dores, processos inflamatórios e infecciosos. O objetivo do estudo foi avaliar a ação antiinflamatória e antinociceptiva do extrato bruto etanólico de Cipura paludosa, nas concentraçóes que variaram entre 2,0 e 4,0\%, em formulaçóes de cremes óleo e água de uso tópico. A estabilidade físico-química das formulaçôes foi monitorada ao longo de um período de seis meses, com a aplicação de ensaios de estabilidade acelerada. A fim de avaliar as atividades anti-inflamatória e antinociceptiva, utilizou-se um teste de edema de pata induzido por carragenina e um teste de formalina, respectivamente. $\mathrm{O}$ teste de edema de pata mostrou que houve uma diferença significativa no grupo controle em relação aos tratamentos. $\mathrm{O}$ teste da formalina não confirmou efeito antinociceptivo dos tratamentos com o extrato, na primeira fase do ensaio. No entanto, a diferença estatística foi confirmada para os tratamentos em relação ao controle na segunda fase. As atividades antinociceptiva e anti-inflamatória das preparaçóes com Cipura paludosa confirmam de forma parcial o uso etno-médico desta planta.
\end{abstract}

PALAVRAS-CHAVES: Creme óleo e água, planta medicinal, teste edema de pata, teste de formalina. 


\section{INTRODUCTION}

Medicinal plants have been a rich source for research on therapeutic molecules. The Cipura paludosa Aubl. (Iridaceae) is found in the Amazon forest in the north of Brazil. The family Iridaceae includes 90 genus and approximately 1500 species (Cunha et al. 2008). It is popularly known as "batata roxa", "alho do mato", "alho da campina", and "cebolinha do campo" among other names. Bulbs of the Cipura paludosa (Iridaceae) are extensively used as a tea by the riverside populations in the Brazilian state of Rondônia (Corrêa 1984).

Certain extracts or active principles obtained from plants of the Iridaceae family have a wide range of biological activities, including anti-bacterial, antiviral, antiprotozarian, antioxidant, anticancer, citotoxic, antinociceptive, and antiinflammatory and immunomodulating activity (Bianchi and Ceriotti 1975; Hosseinzadeh and Younesi 2002; Rahman et al. 2003). Cipura paludosa (Iridaceae) has been used in traditional medicine against disorders such as inflammations, infections, renal tract affections and painful processes (Corrêa 1984).

A recent study has demonstrated the antinociceptive and anti-inflammatory effects of the Cipura paludosa ethanolic extract (CPEE) in mice and rats (Lucena et al. 2007a). The authors also showed that the ethanolic extract of this plant inhibits acetic acid-and-glutamate-induced nociception in mice, as well as inhibits inflammatory processes, suggesting potential "antiglutamatergic" and antioxidant effects of Cipura paludosa (Iridaceae). A second report from the same group has shown that the Cipura paludosa extract prevents methylmercury ( $\mathrm{MeHg}$ )-induced neurotoxicity in adult mice, suggesting an effect of Cipura paludosa (Iridaceae) on the central nervous system (Lucena et al. 2007b).

According to Cunha and Azevedo (2008), a phytochemical study of the Cipura paludosa (Iridaceae) bulb presented a mixture of naftoquinonas called eleuterine and isoeleuterine, in addition to steroids of types $\beta$-sitosterol, estigmasterol e campesterol (Cunha et al. 2008). More recently, a phytochemical analysis was conducted of the CPEE with the use of High Performance Liquid Chromatography (HPLC) and Thin Layer Chromatography (TLC) that showed the presence of terpens and/or steroids, alkaloids, quinoas and phenolic compounds, especially naftoquinona. At least three components were isolated and identified from the acetonic fraction, namely hongconin, eleutherin and isoeleutherin (Lucena et al. 2010). Regarding the therapeutic effects of the popular use of this medicinal plant, the aim of this present study was to evaluate the possibility of transporting the CPEE in a topical formulation, and to verify the anti-inflammatory and antinociceptive action in rats administered with flogistic agents.

\section{MATERIALS AND METHODS}

\section{Preparation of the extract}

A plant of Cipura paludosa (Iridaceae) was collected at the campus of the Federal University of Rondônia, in Porto Velho, in the state of Rondônia, Brazil, grown in an experimental garden. The voucher specimen was deposited at the Herbarium of Dr. Ary Tupinambá Penna Pinheiro (Porto Velho, Brazil), under the number 1782 .

The bulbs of the Cipura paludosa Aubl. (Iridaceae) were washed, cut and dried in an oven at $40{ }^{\circ} \mathrm{C}$, and subsequently the material was macerated with ethanol ( $95 \% \mathrm{v} / \mathrm{v})$ for 7 days at room temperature. The material was filtered and the solvent was evaporated in a rotary vacuum evaporator, yielding the crude ethanolic extract. Previous studies have revealed the presence of flavonoids, alkaloids and terpens in the same type of ethanolic extract (Lucena et al. 2007a; Lucena et al. 2007b; Lucena et al. 2010).

\section{Laboratory animals}

The laboratory animals used in the paw edema tests induced by carrageenan and the $2.5 \%$ formalin tests were male Wistar Rattus novergicus $(n=7)$ rats, each weighing between 230-280 g. The animals were kept under controlled environmental conditions. Food and water were removed 2 hours before the tests were started. This study was approved by the Animal Ethics Committee of the University of Brasilia's Institute of Biology, under the number 100272/2009.

\section{Preparation of the formulation}

The O/W creams were prepared with the phase inversion technique using the pharmaceutical excipients listed in Table 1. The preparation consisted of the separate weighing of the oily and aqueous excipients, with both phases being heated to $70{ }^{\circ} \mathrm{C}$, adding the aqueous phase over the oily one at an agitation rate of $300 \mathrm{rpm}$, in a mechanic agitator (Fisatom, Model 175, São Paulo, Brazil); when $50{ }^{\circ} \mathrm{C}$ was reached, the solubilized extract was added to ethyl alcohol (Ansel et al. 2007; Lachman et al. 2010). The preparation underwent a cooling process under agitation and when $30^{\circ} \mathrm{C}$ was reached, the absorption enhancer, sodium lauril sulphate, was added solubilized in distilled water. Once the preparation of the $\mathrm{O} / \mathrm{W}$ cream was concluded, the $\mathrm{pH}$ value was determined.

\section{Accelerated stability study}

Samples of each formulation were submitted to accelerated stability tests for a period of 180 days, being evaluated at pre-established intervals $(1,15,30,60,90,120,150$ and 180 days). Twenty-four hours after the preparation, the formulations were fractioned in duplicated of $20 \mathrm{~g}$, being conditioned inside plastic pots. The samples were employed in accelerate tests storage temperatures at $4 \pm 2{ }^{\circ} \mathrm{C}, 40 \pm 2$ 
Table 1 - Composition of formulations with concentrations in percentage.

\begin{tabular}{lcc}
\hline \multicolumn{1}{c}{ Ingredients } & $2.0 \%$ Cream & $4.0 \%$ Cream \\
\hline Lanette N & 12.0 & 12.0 \\
\hline Dsodium Edta & 0.1 & 0.1 \\
Propylene glycol & 3.0 & 3.0 \\
Decyl oleate & 4.0 & 4.0 \\
Liquid petrolatum & 5.0 & 5.0 \\
Methylparaben & 0.25 & 0.25 \\
Propylparaben & 0.15 & 0.15 \\
Ethyl alcohol & 5.0 & 5.0 \\
SLS & 1.0 & 1.0 \\
CPEE & 2.0 & 4.0 \\
Distilled water qsp & $100.0 \mathrm{ml}$ & $100.0 \mathrm{ml}$ \\
\hline
\end{tabular}

EDTA $=$ ethylenediaminetetraacetic acid

SLS = sodium lauryl sulfate;

gsp = quantity considered sufficien

CPEE = Cipura paludosa ethanolic extract

${ }^{\circ} \mathrm{C}$ at $75 \%$ relative humidity and room temperature $(25 \pm 2$ $\left.{ }^{\circ} \mathrm{C}\right)$. The organoleptic characteristics were evaluated during stability test. The $\mathrm{pH}$ of all formulations was verified at room temperature, right after preparation and during the 180 days, by employing a digital potenciometer (Gehaka, Model 1500, São Paulo, Brazil). Centrifugation was carried out in duplicated of $2 \mathrm{~g}$ of each formulation at (1575 g) for 15 minutes in a centrifuge (Centribio, Model 80-2B, Belo Horizonte, Brazil) (Brazil 2004; 2005).

\section{The paw edema test induced with carrageenan injection}

The anti-inflammatory activity research was carried out with 4 groups of animals by treatment: negative control (base cream), positive control ( $0.5 \%$ piroxicam gel), 2.0 and $4.0 \%$ CPEE creams.

The paw edema was induced by injecting $0.1 \mathrm{~mL}$ of carrageenan $(1.0 \% \mathrm{w} / \mathrm{v})$ diluted in a saline solution and administered in the intraplantar region of the right paw of the Wistar rat (Winter 1962; Shin et al. 2000; Süleyman et al. 2003). The left paw received a volume of $0.9 \%$ saline solution. Samples of $0.2 \mathrm{~g}$ of the formulations were rubbed on the right paw 50 times, 1 hour before the carrageenan injection. Animals in the negative control group received the base cream (no extract). One group of rats received $0.5 \%$ piroxicam gel (positive control) for comparison with the other treatments.

The volume of the rat paw was measured with a calibrated plastic tube before the intraplantar stimulus with carrageenan and at 1, 2, 3, 4 and 5 hours after the injection of carrageenan. When the rat paw was placed in a calibrated plastic tube, the displacement volume permitted an evaluation of the swelling. The average of three readings for each paw was calculated by subtracting the size of the right paw from that of the left paw (Winter 1962).

\section{Antinociceptive activity using the formalin test}

The test was conducted on four groups of animals by treatment: negative control (base cream), positive control (methyl salicylate ointment), 2.0 and 4.0\% CPEE creams. One hour before administering formalin on the right paw of each rat, $0.2 \mathrm{~g}$ of the $\mathrm{O} / \mathrm{W}$ creams under study and that of the controls was applied to the surface of the right hind paw of the rats, by light friction 50 times with the index finger. One hour after the application of the formulation on each animal, $20 \mu \mathrm{L}$ of formalin $2.5 \%$ was administered to the right paw that had received the treatment. After the injection of formalin, the rat was observed for 30 minutes. The time (in seconds) spent in licking and biting responses of the injected paw was taken as an indicator of pain response. Responses were measured for 5 minutes after formalin injection (neurogenic phase) and 15-30 minutes after formalin injection (inflammatory phase) (Dubuisson and Denis 1977; Semnani et al. 2004; Sousa et al. 2009).

\section{Statistical analysis}

All values are expressed as the mean \pm S.E.M. of seven animals in each group. The statistical comparison of results was carried out using one-way analysis of variance (ANOVA). Subsequent multiple post-hoc comparisons were performed using the Newman-Keuls test. The accepted level of significance for the tests was $\mathrm{P}<0.05$. All tests were performed using the GraphPad Prism 5 software package (La Jolla, CA, USA).

\section{RESULTS}

\section{Stability of the formulations}

The O/W creams with 2.0 and 4.0\% CPEE were stable at room temperature, $4 \pm 2{ }^{\circ} \mathrm{C}$ and $40 \pm 2{ }^{\circ} \mathrm{C}$ at $75 \%$ relative humidity. The $\mathrm{pH}$ value for both 2.0 and $4.0 \% \mathrm{O} / \mathrm{W}$ creams remained between 5.0 and 5.5 (Tables 2 and 3). In the centrifuge test, precipitation of the extract took place at 180 days for the $2.0 \%$ cream and 150 days for the $4.0 \%$ cream, but this did not interfere with stability, since the same creams that were kept at room temperature $\left(25 \pm 2{ }^{\circ} \mathrm{C}\right)$ did not manifest any physical alterations regarding odour, colour or the separation of the phases.

Considering that the variations in the physical and chemical stability of the 2.0 and $4.0 \% \mathrm{O} / \mathrm{W}$ creams were not significant, the formulations were considered stable.

\section{The paw edema test induced by carrageenan}

The tests to evaluate the anti-inflammatory and antinociceptive activities of the 2.0 and $4.0 \% \mathrm{O} / \mathrm{W}$ creams were performed after the stability assessment. There was a statistical difference between the control (base cream) and $4.0 \%$ cream after 2 hours in the paw edema test induced by 
Table 2 - Results of the stability test of $2.0 \%$ cream until 180 days.

\begin{tabular}{|c|c|c|c|c|c|c|c|c|c|c|c|}
\hline \multirow[b]{2}{*}{ Time (days) } & \multicolumn{3}{|c|}{ Colour } & \multicolumn{3}{|c|}{ Odour } & \multicolumn{3}{|c|}{ Phase separation } & \multirow{2}{*}{$\begin{array}{c}\text { Centrifugation } \\
25^{\circ} \mathrm{C}\end{array}$} & \multirow{2}{*}{$\begin{array}{c}\mathrm{pH} \\
25^{\circ} \mathrm{C}\end{array}$} \\
\hline & $4^{\circ}$ & $40^{\circ}$ & $25^{\circ}$ & $4^{\circ}$ & $40^{\circ}$ & $25^{\circ}$ & $4^{\circ}$ & $40^{\circ}$ & $25^{\circ}$ & & \\
\hline 1st & $\begin{array}{c}Y \\
\text { BR }\end{array}$ & $\begin{array}{c}\mathrm{Y} \\
\mathrm{BR}\end{array}$ & $\begin{array}{c}\mathrm{Y} \\
\mathrm{BR}\end{array}$ & O.S. & o.s. & O.S. & $(-)$ & $(-)$ & $(-)$ & WS & 5.5 \\
\hline 15th & $\begin{array}{c}Y \\
B R\end{array}$ & $\begin{array}{c}Y \\
\text { BR }\end{array}$ & $\begin{array}{c}Y \\
B R\end{array}$ & O.S. & O.S. & O.S. & $(-)$ & $(-)$ & $(-)$ & WS & 5.56 \\
\hline 30th & $\begin{array}{c}Y \\
\text { BR }\end{array}$ & $\begin{array}{c}Y \\
\text { BR }\end{array}$ & $\begin{array}{c}Y \\
B R\end{array}$ & $0 . S$ & $0 . S$ & $0 . S$ & $(-)$ & $(-)$ & $(-)$ & WS & 5.57 \\
\hline 60th & $\begin{array}{c}Y \\
O P\end{array}$ & $\begin{array}{c}Y \\
\text { BR }\end{array}$ & $\begin{array}{c}Y \\
\text { BR }\end{array}$ & $0 . S$ & $0 . S$ & $0 . S$ & $(-)$ & $(-)$ & $(-)$ & WS & 5.54 \\
\hline 90th & $\begin{array}{c}Y \\
O P\end{array}$ & $\begin{array}{c}Y \\
\text { BR }\end{array}$ & $\begin{array}{c}Y \\
\text { BR }\end{array}$ & $0 . S$ & $0 . S$ & $0 . S$ & $(-)$ & $(-)$ & $(-)$ & WS & 5.54 \\
\hline 120th & $\begin{array}{c}Y \\
O P\end{array}$ & $\begin{array}{c}Y \\
\text { BR }\end{array}$ & $\begin{array}{c}Y \\
B R\end{array}$ & $(+)$ & $(+)$ & $0 . S$ & $(-)$ & $(-)$ & $(-)$ & WS & 5.54 \\
\hline 150th & $\begin{array}{c}Y \\
O P\end{array}$ & $\begin{array}{c}Y \\
B R\end{array}$ & $\begin{array}{c}Y \\
B R\end{array}$ & $(+)$ & $(+)$ & 0.5 & $(-)$ & $(-)$ & $(-)$ & WS & 5.45 \\
\hline 180th & $\begin{array}{c}Y \\
O P\end{array}$ & $\begin{array}{c}Y \\
B R\end{array}$ & $\begin{array}{c}Y \\
B R\end{array}$ & $(+)$ & $(+)$ & $0 . S$ & $(-)$ & $(-)$ & $(-)$ & $(++)$ & 5.27 \\
\hline
\end{tabular}

$(-)$ = without alteration; $(+)=$ alteration; $(++)=$ Phase separation; 0.S. = suis generis odour; $\mathrm{Y}=$ yellow; $\mathrm{BR}=$ Brightness; $\mathrm{OP}=0$ paque; WS= Without separation.

Table 3 - Results of the stability test of $4.0 \%$ cream until 180 days.

\begin{tabular}{|c|c|c|c|c|c|c|c|c|c|c|c|}
\hline \multirow[b]{2}{*}{ Time (days) } & \multicolumn{3}{|c|}{ Colour } & \multicolumn{3}{|c|}{ Odour } & \multicolumn{3}{|c|}{ Phase separation } & \multirow{2}{*}{$\begin{array}{c}\text { Centrifugation } \\
25^{\circ} \mathrm{C}\end{array}$} & \multirow{2}{*}{$\frac{\mathrm{pH}}{25^{\circ} \mathrm{C}}$} \\
\hline & $4^{\circ}$ & $40^{\circ}$ & $25^{\circ}$ & $4^{\circ}$ & $40^{\circ}$ & $25^{\circ}$ & $4^{\circ}$ & $40^{\circ}$ & $25^{\circ}$ & & \\
\hline $1 \mathrm{st}$ & $\begin{array}{c}\text { B } \\
\text { BR }\end{array}$ & $\begin{array}{c}\text { B } \\
\text { BR }\end{array}$ & $\begin{array}{c}\text { B } \\
\text { BR }\end{array}$ & o.S. & O.S. & o.S. & $(-)$ & $(-)$ & $(-)$ & WS & 5.5 \\
\hline 15th & $\begin{array}{c}\text { B } \\
\text { BR }\end{array}$ & $\begin{array}{c}\text { B } \\
\text { BR }\end{array}$ & $\begin{array}{c}\text { B } \\
\text { BR }\end{array}$ & o.s. & O.S. & o.S. & $(-)$ & $(-)$ & $(-)$ & WS & 5.56 \\
\hline 30th & $\begin{array}{c}\text { B } \\
B R\end{array}$ & $\begin{array}{c}\text { B } \\
B R\end{array}$ & $\begin{array}{c}\text { B } \\
B R\end{array}$ & $0 . S$ & $0 . S$ & $0 . S$ & $(-)$ & $(-)$ & $(-)$ & WS & 5.5 \\
\hline 60th & $\begin{array}{c}\text { B } \\
\text { BR }\end{array}$ & $\begin{array}{c}\text { B } \\
\text { BR }\end{array}$ & $\begin{array}{c}\mathrm{B} \\
\mathrm{BR}\end{array}$ & $0 . S$ & $0 . S$ & $0 . S$ & $(-)$ & $(-)$ & $(-)$ & WS & 5.36 \\
\hline 90th & $\begin{array}{c}\text { B } \\
\text { BR }\end{array}$ & $\begin{array}{c}\text { B } \\
\text { BR }\end{array}$ & $\begin{array}{c}\mathrm{B} \\
\mathrm{BR}\end{array}$ & $0 . S$ & O.S & $0 . S$ & $(-)$ & $(-)$ & $(-)$ & WS & 5.4 \\
\hline 120th & $\begin{array}{c}\text { B } \\
\text { BR }\end{array}$ & $\begin{array}{c}\text { B } \\
\text { BR }\end{array}$ & $\begin{array}{c}\mathrm{B} \\
\mathrm{BR}\end{array}$ & $(+)$ & $0 . S$ & $0 . S$ & $(-)$ & $(-)$ & $(-)$ & WS & 5.45 \\
\hline 150th & $\begin{array}{c}B \\
O P\end{array}$ & $\begin{array}{c}\text { B } \\
\text { BR }\end{array}$ & $\begin{array}{c}\text { B } \\
\text { BR }\end{array}$ & $(+)$ & $(+)$ & $0 . S$ & $(-)$ & $(-)$ & $(-)$ & $(++)$ & 5.04 \\
\hline 180th & $\begin{array}{c}B \\
O P\end{array}$ & $\begin{array}{c}B \\
B R\end{array}$ & $\begin{array}{c}\text { B } \\
\text { BR }\end{array}$ & $(+)$ & $(+)$ & $0 . S$ & $(-)$ & $(-)$ & $(-)$ & $(++)$ & 5.0 \\
\hline
\end{tabular}

$(-)=$ without alteration; $(+)=$ alteration; $(++)=$ Phase separation; $0 . S$. = suis generis odour; $B=$ Brown; $B R=$ Brightness; OP $=0$ paque; WS $=$ Without separation

carrageenan. After 3 hours, the same was true for the base and $4.0 \%$ creams, but there was a difference between the control and the piroxicam gel and the 2.0 and $4.0 \%$ creams. After 4 hours of test there was a statistical difference only between the control and piroxicam gel, as may be seen in (Figure 1).

This result shows that after 2 hours the base cream presented a significant edema in relation to $4.0 \%$ cream, statistically showing that the $4.0 \%$ Cipura paludosa ethanolic extract reduced the edema in comparison with the other treatments. After 3 hours, the same thing happened, but with the difference that there was a statistical difference between the control and all the treatments.

The paw edema inhibition values of the 2.0 and $4.0 \%$ $\mathrm{O} / \mathrm{W}$ cream formulations were statistically different from the control group (base cream). This is because the edema inhibition is an activity that depends on the dose and the period, as per (Figure 2). The ANOVA, followed by the Newman Keuls post hoc, showed a statistical difference among the treatments $\left[\mathrm{F}_{(19,139)}=1.838, \mathrm{P}<0.05\right]$. This was observed after 1 hour for the piroxicam gel and the $2.0 \%$ cream in relation to the control; and after 2 hours, this difference was 


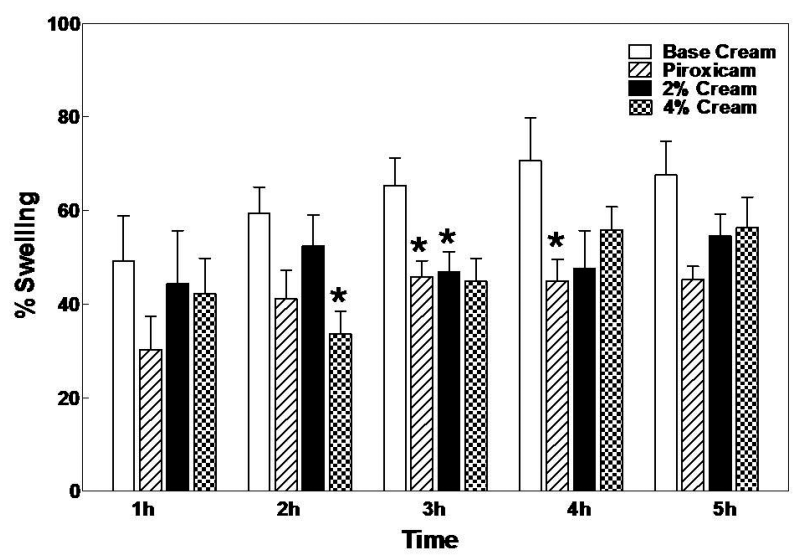

Figure 1 - Effect of the topical administration of Oil and Water cream formulations with the Cipura Paludosa ethanolic extract on the paw edema induced by carrageenan in rats. The results represent 7 animals by treatment. ${ }^{*} \mathrm{P}<0.05$ represents a statistical difference in relation to control animals treated with the base cream, according to each specific time $-2,3$ or $4 \mathrm{~h}$ (ANOVA, Newman-Keuls test).

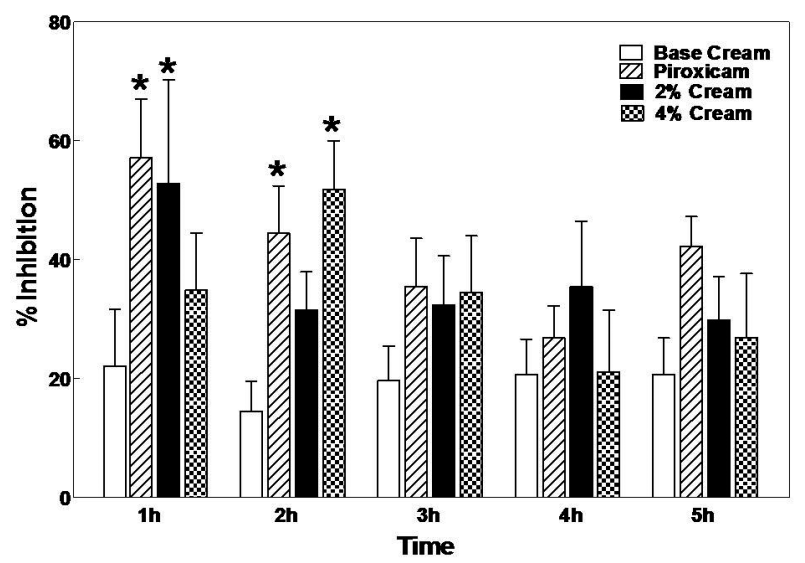

Figure 2 - Effect of the inhibition of the edema of the Cipura paludosa ethanolic extract in Oil and Water cream formulations at concentrations of 2.0 and $4.0 \%$ in rats evaluated in the carrageenan-induced paw edema tests during the 5 hours of the test. The results represent 7 animals per treatment. ${ }^{*} P 0.05$ represents a statistical difference in relation to control animals treated with the base cream, according to each specific time -1 or 2 hours (ANOVA, Newman-Keuls test).

observed for piroxicam gel and $4.0 \%$ cream in relation to the control. It is possible to observe in (Figure 2) that the 2.0 and $4.0 \% \mathrm{O} / \mathrm{W}$ cream formulations presented edema inhibition percentages ranging between $52.79 \%$ and $34.81 \%$ after 1 hour, and $31.54 \%$ and $51.86 \%$ after 2 hours, respectively.

\section{Formalin test}

During the neurogenic phase $(0-5 \mathrm{~min})$ of the $2.5 \%$ formalin test, it was observed that for both 2.0 and $4.0 \%$ $\mathrm{O} / \mathrm{W}$ cream formulations there was no statistical difference in relation to the control (base cream) when administered

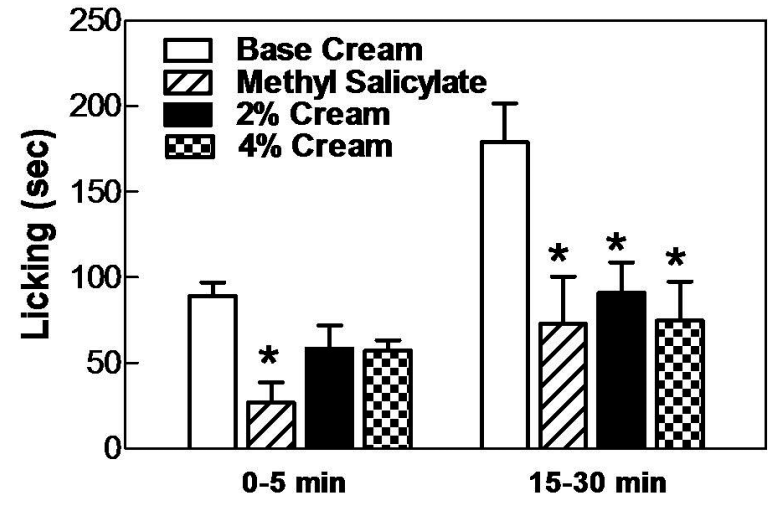

Figure 3 - Evaluation of the antinociceptive activity of Oil and Water cream formulations with Cipura paludosa ethanolic extract in concentrations of 2.0 to $4.0 \%$ in rats evaluated in the formalin test $(2.5 \%) .0-5$ min represents the early phase; $15-30 \mathrm{~min}$ represents the late phase. The results represent the mean \pm S.E.M of 7 animals. ${ }^{*} P<0.05$ represents a statistical difference in relation to control animals treated with the base cream, for each one of the phases (ANOVA, Newman-Keuls test).

topically. The effects of 2.0 and $4.0 \% \mathrm{O} / \mathrm{W}$ cream formulations in the formalin test are presented in (Figure 3).

The nociception test induced by formalin showed that 2.0 and $4.0 \% \mathrm{O} / \mathrm{W}$ cream formulations presented a significant difference in relation to the control group (base cream) only in the late phase $\left[\mathrm{F}_{(7,63)}=6.230, \mathrm{P}<0.001\right]$. The positive control, i.e., the methyl salicylate ointment, was effective in both phases.

\section{DISCUSSION}

Carrageenan-induced paw edema is commonly used as an experimental model of acute inflammation. In the present study, an attempt has been made to evaluate the anti-inflammatory activity of Cipura paludosa (Iridaceae) in topical formulations using the carrageenan-induced paw edema model. The results of this investigation indicate that the Cipura paludosa ethanolic extract has a marked ability to counter acute inflammation induced by carrageenan.

Recently, the Cipura paludosa (Iridaceae) has been extensively studied for its pharmacological properties of ethanolic extract, fractions and isolated compounds from the bulbs of this plant. Previous studies have indicated a series of biological activities for Cipura paludosa (Iridaceae) including antinociceptive and anti-inflammatory (Lucena $e t$ al. 2007a), and antioxidant and antiglutamatergic (Lucena et al. 2007b) effects. The anti-allodynic action of the active principle(s) present in the ethanolic extract of Cipura paludosa is most probably associated with its anti-inflammatory action. This notion is further reinforced by the results showing that the acute administration of the ethanolic extract of Cipura 
paludosa caused a pronounced inhibition of paw edema formation. These results are interesting and clearly suggest that active principle(s) present in the ethanolic extract of Cipura paludosa are likely to be responsible for its anti-allodynic and anti-inflammatory properties (Lucena et al. 2007a).

More recently, the in vivo effects of the major compounds (eleutherine and isoeleutherine) have been demonstrated in different models of hypernociception and inflammation in mice (Tessele et al. 2011), justifying, at least in part, the popular therapeutic use for treating conditions related to inflammation and dolorous processes.

The topical administration of drugs implicates the passage of the drugs through the layers of skin, namely the epidermis, dermis and hypodermis. Considering that the epidermis has a corneous stratum through which it is difficult to pass, topical application has limitations regarding the passage of drugs. This may be improved with the inclusion of absorption enhancers in topical formulations to reduce the barrier function of the corneous stratum (Aulton et al. 2005; Maghraby 2008). For reducing the barrier of corneous stratum, sodium lauril sulphate and propylene glycol were added to the composition of the 2.0 and $4.0 \% \mathrm{O} / \mathrm{W}$ creams as absorption enhancers (Ansel et al. 2007).

The paw edema test induced by carrageenan is widely used to evaluate the anti-inflammatory activity of topical products, and reductions in edemas which frequently take place in the second and third hour after application. Edema induced by carrageenan is a two-phase model, with various mediators acting in sequence to produce the antiinflammatory response. In the initial phase (0-1 h), histamine, serotonin and bradykinin are released. The subsequent phase (1-6 h) is correlated with the high production of prostaglandins, activation of Cyclooxygenase-2 (COX-2) and, more recently, the release of nitric oxide has been identified, in the inflammatory response (Vinegar et al. 1969; Silva et al. 2005; Gorzalczany et al. 2011). Carrageenan triggers an inflammatory process mediated by prostaglandins, reaching peak levels 2 to 3 hours after application (Sartori et al. 2003).

The inhibition of carrageenan-induced edemas involves a mechanism related to the reduction in the production of prostaglandins, particularly PGE2 $\alpha$ and PGF $2 \alpha$, an activity that can be compared to non-steroidal anti-inflammatory activity (Sartori et al. 2003).

Piroxicam is a well-established non-steroidal antiinflammatory drug (NSAID) exhibiting anti-inflammatory properties. It is widely used for rheumatic diseases because of its potent anti-inflammatory properties and long halflife offering the convenience of a once-daily administration (Csóka et al. 2005; Rasetti-Escargueil et al. 2005). Due to these properties, it was chosen as the drug of reference in the paw edema test.
The formalin test is considered a sensitive and reliable antinociceptive model for various classes of analgesic drugs. It is a valuable method available to study nociception, because the formalin injection may induce a state that is a closer approximation to clinical conditions (Tjølsen et al. 1992). Central action drugs, such as opiates, inhibit both phases equally, but drugs with peripheral action, such as aspirin, indomethacin and dexamethasone only inhibit the late phase. The late phase appears to be an inflammatory phase that may be inhibited by anti-inflammatory drugs (Calvo et al. 2006; Nonato et al. 2011).

Although previous studies have shown that the Cipura paludosa ethanolic extract presented an antinociceptive effect when administered orally in rats and mice (Lucena et al. 2007a), the same has not been observed when administered topically.

During the test, the early phase $(0-5 \mathrm{~min})$ corresponds to the neurogenic phase in which an intensely painful process takes place with the activation of the nociceptive channels. The inflammation mediators and inflammation are produced 15 min after formalin is applied (late phase). According to Shibata et al. (1989), substance $P$ and bradykinin act as mediators in the early phase, while histamine, serotonin, prostaglandin and bradykinin are involved in the nociceptive response in the late phase (Andrade et al. 2007; Sousa et al. 2009).

Methyl salicylate was used as positive control in the formalin test. In the literature this drug shows positive results for the reduction of edema. Similar results for methyl salicylate were also observed in a study of a drug involving an extract of Glaucium grandiflorum in a topical preparation (Semnani et al. 2004). In another study on the formalin test, the methyl salicylate ointment produced significant $(\mathrm{P}<0.01)$ inhibition in both phases with cream containing 0.4 and $0.5 \%$ kirenol (Wang et al. 2011).

The effect of the Cipura paludosa ethanolic extract in the late phase of the formalin test suggests that its activity may be the result of its peripheral action when compared to indomethacin activity. Many studies that depict the analgesic action of plant extracts compare late phase action with drugs that act peripherally, such as indomethacin, aspirin and dexamethasone (Calvo et al. 2006; Nonato et al. 2011; Wang et al. 2011).

Based on the overall results, it may be concluded that the topical preparation of an $\mathrm{O} / \mathrm{W}$ cream containing an ethanolic extract of Cipura paludosa produced an anti-inflammatory effect, which may be useful in treating local inflammation. Previous phytochemical studies of this plant have shown the presence of terpins, steroids, alkaloids, quinines and fenolic compounds, as well as hongconin, eleutherin e isoeleutherin compounds (Lucena et al. 2007a; Lucena et al. 2007b, Lucena et al. 2010). It is possible that the anti-inflammatory effect 
attributed to the extract may be partially attributed to these compounds.

\section{ACKNOWLEDGEMENTS}

The authors would like to thank CAPES (Coordenação de Aperfeiçoamento de Pessoal de Nível Superior) and FINATEC (Fundação de Empreendimentos Científicos e Tecnológicos) for the financial support, Dr. Setsuko Noro dos Santos for collaboration and the University of Rondônia for donation of the extract of Cipura paludosa.

\section{REFERENCES}

Andrade, S.F.; Cardoso, L.G.V.; Carvalho, J.C.T.; Bastos, J.K. 2007. Anti-inflammatory and antinociceptive activities of extract, fractions and populnoic acid from bark wood of Austroplenckia populnea. Journal of Ethnopharmacology, 109: 464-471.

Ansel, H.C.; Popovich, N.G.; Allen, L.V. 2007. Delineamento de Formas Farmacêuticas e Sistemas de Liberação de Fármacos, $8^{\text {a }}$ ed. Artmed, Porto Alegre, 2007, 775p.

Aulton, E.M. 2005. Delineamento de Formas Farmacêuticas, 2a ed. Artmed, Porto Alegre, 2005, 678p.

Bianchi, C.; Ceriotti, G. 1975. Chemical and pharmacological investigations of constituents of Eleutherine bulbosa (Miller) Urb. (Iridaceae). Journal of Pharmaceutical Science, 64: 13051308.

Brazil, 2004. Guia de estabilidade de produtos cosméticos, vol. 1. Available at: www.anvisa.gov.br Accessed on 29/07/2012

Brazil, 2005. RE no 1. "Guia para realização de estudos de estabilidade" Diário Oficial da União. Brasília DF. Available at: www.anvisa.gov.br Accessed on 29/07/2012

Calvo, M.I. 2006. Anti-inflammatory and analgesic activity of the topical preparation of Verbena officinalis L. Journal of Ethnopharmacology, 107: 380-382.

Corrêa, M.P. 1984. Dicionário das plantas úteis do Brasil e das exóticas cultivadas. Ministério da Agricultura. Instituto Brasileiro de Desenvolvimento Florestal, Rio de Janeiro, vol. I, 1984, 78p.

Csóka, I.; Csányi, E.; Zapantis, G.; Nagy, E.; Fehér-Kiss, A.; Horváth, G.; Blazsó, G.; Erós, I. 2005. In vitro and in vivo percutaneous absorption of topical dosage forms: studies cases. International Journal of Pharmaceutics, 291: 11-19.

Cunha, E.M.F.; Azevedo, M.S. Estudo Químico da Cipura paludosa Aubl. (IRIDACEAE). Available at: www.pibic.unir.br Accessed on $12 / 12 / 2008$

Dubuisson, D. \& Dennis, S.G. 1977. The formalina test: a quantitative study of analgesic effects of morphine, meperidine, and brain stem stimulation in rats and cats. Pain, 4: 161-174.

Gorzalczany, S.; López, P.; Acevedo, C.; Ferraro, G. 2011. Antiinflammatory effect of Lithrea molleoides extracts and isolated active compounds. Journal of Ethnopharmacology, 133: 994998.
Hosseinzadeh, H.; Younesi, H.M. 2002. Antinociceptive and antiinflammatory effects of Crocus sativus L., stigma and petal extracts in mice. BioMed Central Pharmacology, 15: 2-7.

Lachman, L.; Lieberman, H.A.; Kaning, J.L. 2010. Teoria e prática na indústria farmacêutica, $2^{\mathrm{a}} \mathrm{ed}$. Fundação Calouste Gulberkian, Lisboa, 2010, 2030p.

Lucena, G.M.R.S.; Gadotti, V.M.; Maffi, L.C; Silva, G.S.; Azevedo, M.S.; Santos, A.R.S. 2007a. Antinociceptive and antiinflammatory properties from the bulbs of Cipura paludosa Aubl. Journal of Ethnopharmacology, 112: 19-25.

Lucena, G.M.R.S.; Franco, J.L.; Ribas, C.M.; Azevedo, M.S.; Meotti, F.C.; Gadotti, V.M.; Dafre, A.L.; Santos, A.R.; Farina, M. 2007b. Cipura paludosa extract prevents methyl Mercuryinduced neurotoxicity in mice. Basic \& Clinical Pharmacology \& Toxicology, 101: 127-131.

Lucena, G.M.R.S.; Porto, F.A.; Campos, E.G.; Azevedo, M.S.; Checinel-Filho, V.; Prediger, R.D.S.; Ferreira, V.M. 2010. Cipura paludosa attenuates long-term behavioral deficits in rats exposed to methylmercury during early development. Ecotoxicology and Environmental Safety, 73: 1150-1158.

Maghraby, G.M.E. 2008. Transdermal delivery of hydrocortisone from eucalyptus oil microemulsion: Effects of cosurfactants. International Journal of Pharmaceutics, 355: 285-292.

Nonato, F.R; Nogueira, T.M.O.; Barros, T.A.A.; Lucchese, A.M.; Oliveira, C.E.C; Santos, R.R.; Soares, M.B.P.; Villarreal, C.F. 2011. Antinociceptive and Antiinflammatory activities of Adiantum latifolium Lam.: Evidence for a role of IL-1ß inhibition. Journal of Ethnopharmacology, 136: 518-524.

Rahman, A.U.; Nasim, S.; Baig, I.; Jalil, S.; Orhan, I.; Sener, B.; Choudhary, M.I. 2003. Anti-inflammatory isoflavonoids from the rhizomes of Iris germanica. Journal of Ethnopharmacology, 86: $177-180$.

Rasetti-Escargueil, C.; Grangé, V. 2005. Pharmacokinetic profiles of two tablet formulations of piroxicam. Internacional Journal of Pharmaceutics, 295: 129-134.

Sartori, L.R.; Ferreira, M.S.; Perazzo, F.F.; Mandalho L.L.; Carvalho, J.C.T. 2003. Atividade anti-inflamatória do granulado de Calendula officinalis L. e Matricaria recutita L. Revista Brasileira de Farmacognosia, 13: 17-19.

Semnani, K.M.; Saeedi, M.; Hamidian, M. 2004. Anti-inflammatory and analgesic activity of the topical preparation of Glaucium grandiflorum. Fitoterapia, 75: 123-129.

Shibata, M.; Ohkubo, T.; Takahashi, H.; Inoki, R. 1989. Modified formalin test: characteristic biphasic pain response. Pain, 38: 347-52.

Shin, S.C.; Cho, C.W.; Oh, I.J. 2000. Enhanced efficacy by percutaneous absorption of piroxicam from the polaxamer gel in rats. Internacional Journal of Pharmaceutics, 193: 213-218.

Silva, M.G.; Oliveira, F.S.; Quintans-Junior, L.J.; Oliveira, T.M.L.; Diniz, M.F.F.M. 2005. Investigação do Efeito Analgésico Central e Anti-inflamatório de Conocliniopsis prasiifolia (DC) R.M. King \& H. Robinson em Roedores. Acta Farmacéutica Bonaerense, 24: 533-537. 
Sousa, O.V.; Fioravante, I.A.; Del-Vechio-Vieira, G.; Caneschi C.A. 2009. Investigação das atividades antinociceptiva e antiedematogênica do extrato etanólico das folhas de Joannesia princeps Vellozo. Revista de Ciências Farmacêuticas Básica Aplicada, 30: 77-83.

Süleyman, H.; Gul, H.I.; Asoglu, M. 2003. Anti-inflammatory activity of 3-benzoyl-1-methyl-4-phenyl-4-piperidinol hydrochloride. Pharmacological Research, 47: 471-475.

Tessele, P.B.; Delle Monache, F.; Quintão, N.L.; da Silva, G.F.; Rocha, L.W.; Lucena, G.M.; Ferreira, V.M.; Prediger, R.D.; Cechinel Filho, V. 2011. A new naphthoquinone isolated from the bulbs of Cipura paludosa and pharmacological activity of two main constituents. Planta Medica, 77: 1035-1043.

Tjølsen, A.; Berge, O.G.; Hunskaar, S.; Rosland, J.H.; Hole, K. 1992. The formalin test: an evaluation of the method. Pain, 51: 5-17.
Vinegar, R.; Schreiber, W.; Hugo, R. 1969. Biphasic development of carrageenan

edema in rats. Journal of Pharmacology and Experimental Therapeutics, 166: 96-103.

Wang, J.P.; Zhou, Y.M.; Ye, Y.J.; Shang, X.M.; Cai, Y.L.; Xiong, C.M.; Wu, Y.X.; Xu, H.X. 2011. Topical anti-inflammatory and analgesic activity of kirenol isolated from Siegesbeckia orientalis. Journal of Ethnopharmacology, 137: 1089-1094.

Winter, C.A.; Risley, E.A.; Nuss, G.W. 1962. Carrageenan-induced edema in hind paw of the rat as an assay for anti-inflammatory drugs. Proceedings of the Society for Experimental Biology and Medicine, 111: 544-547.

Recebido em 27/01/2013

Aceito em 05/07/2013 